кuLTura- MeDia- TeoLogia

ISSN 2081-8971

$2017 \mathrm{nr} 29$, s. $46-57$.

Karolina Ołtarzewska, WNHiS UKSW

\title{
Reakcje użytkowników Twittera \\ na wiadomość 0 wypadku z udziałem prezydenckiej limuzyny
}

Iwitter users' reaction for the news of an accident with the presidential limousine.

\section{STRESZCZENIE:}

WYPADEK Z UDZIAEEM PREZYDENCKIEJ LIMUZYNY, KTÓRY MIAŁ MIEJSCE 4 MARCA 2016 ROKU BYŁ SZEROKO KOMENTOWANY PRZEZ INTERNAUTÓW W SERWISIE SPOŁECZNOŚCIOWYM TWITTER. WPISY UŻYTKOWNIKÓW

TWITTERA STANOWIĄ CIEKAWY MATERIAŁ BADAWCZY,

A ODPOWIEDNIO USYSTEMATYZOWANY POZWALA WYCIĄGNĄĆ WNIOSKI. BAZUJĄC NA LITERATURZE MOŻNA

STWIERDZIĆ, ŻE KRYZYS JAKI WÓWCZAS WYBUCHŁ ZOSTAE PRZYPORZĄDKOWANY DO RODZAJU WROGOŚCI I POGŁOSEK. MA TO REALNE ZNACZENIE NA KSZTAŁTOWANIE OPINII PUBLICZNEJ ZE WZGLĘDU NA CHARAKTER OPINIOTWÓRCZY ANALIZOWANEGO SERWISU SPOŁECZNOŚCIOWEGO I DANE, KTÓRE MÓWIĄ, ŻE OK. 75\% CYTOWAŃ Z TWITTERA POJAWIA SIĘ W RADIU, 68\% W TELEWIZJI ORAZ 35\% W PRASIE. MATERIAŁ BADAWCZY POZWOLIŁ WYODRĘBNIĆ WPISY POZYTYWNE, NEGATYWNE I NEUTRALNE. W OSTATECZNOŚCI ANALIZA

WYKAZAŁA, ŻE NAJLICZNIEJSZĄ GRUPĄ BYŁY TWEETY

NEUTRALNE - 7728 TWEETÓW, CO STANOWI 66\%

CAŁOŚCI. WPISÓW UZNANYCH ZA NEGATYWNE BYŁO 3030 TJ. 26\%, ZAŚ WPISÓW POZYTYWNYCH MOŻNA BYŁO W WYNIKACH ZAUWAŻYĆ 918, CO STANOWIŁO 8\% UDZIAŁU WSZYSTKICH TWEETÓW. UZYSKANY WYNIK ANALIZY MOŻE ŚWIADCZYĆ O TYM, ŻE NA TLE LICZBY POZYTYWNYCH WPISÓW NEGATYWNE CIESZYŁY SIE WIĘKSZĄ POPULARNOŚCIĄ NA TWITTERZE, CO JEST PRZYKŁADEM NA POGŁĘBIAJĄCĄ SIĘ MOWĘ NIENAWIŚCI W SIECI.

\section{SEOWA KLUCZOWE:}

TWITTER, MEDIA SPOŁECZNOŚCIOWE, MONITORING MEDIÓW

\begin{abstract}
:
AN ACCIDENT WITH THE PRESIDENTIAL LIMOUSINE WHICH TOOK PLACE IN 4 MARCH, 2016 WAS COMMENTED ON TWITTER. THEIR INSCRIPTIONS TOOK SOME INTERESTING SCIENCE MATERIAL, WHICH CAN GIVE CONCLUSIONS. WHEN WE BASED ON SOCIAL MEDIA LITERATURE WE CAN STATE THAT CRISIS CONNECTED WHICH THE CRASH WAS ASSIGNED TO “HATE” AND “RUMOR” CATEGORIES. IT HAS VERY HARD INFLUENCE FOR THE PUBLIC OPINION, BECAUSE THE RADIO IS QUOTE ABOUT 75\% TWITTER'S TWEETS, $68 \%$ TV AND 35\% PRESS. FROM PRESENTED SCIENCE MATERIAL WE CAN EXTRACT POSITIVE, NEGATIVE AND NEUTRAL COMMENTS. THE MOST POPULAR OF GROUP WAS NEUTRAL TWEETS (ABOUT 26\%). BUT POSITIVE TWEETS PROVIDE ONLY 8\%. THE RESULT OF THIS RESEARCH IT CAN INDICATED THAT NEGATIVES TOOK POPULARITY ON POLISH TWITTER AND COULD BE EXAMPLE FOR HATING AND TROLLING ON THE INTERNET.
\end{abstract}

\section{KEYWORDS:}

TWITTER, SOCIAL MEDIA, MEDIA WATCH 
M edia społecznościowe dają wiele możliwości w kreowaniu wizerunku organizacji i z początkiem drugiej dekady XXI wieku stały się nieodłącznym narzędziem komunikacyjnym wspierającym tradycyjne public relations. Już w 2011 roku według badań przeprowadzonych przez Instytut Monitorowania Mediów na specjalistach PR wykazano, że $77 \%$ badanych $^{1}$ uważało, że media społecznościowe mogą pomóc w zarządzaniu kryzysem. Jednak prawie $2 / 3$ z badanych osób przyznało, że nie wie, jak skutecznie wykorzystać social media w komunikacji z publicznościami. Podobnie było z pytaniem o wiedzę na temat monitoringu mediów i jego wykorzystania w budowaniu strategii komunikacyjnej².

\section{Pojęcie i znaczenie monitoringu mediów}

Obecnie znaczna większość agencji interaktywnych nie wyobraża sobie obsługi klienta bez wykorzystania odpowiednio dobranego do potrzeb branży narzędzia. Monitorowanie mediów społecznościowych jest określane jako proces ciągłego obserwowania i wsłuchiwania się $w$ treści zawarte $\mathrm{w}$ serwisach społecznościowych, a następnie ich identyfikowanie, zapisywanie oraz analizowanie wyników zawierających określone słowa kluczowe związane z określonym tematem ${ }^{3}$. Wyspecjalizowane do tego narzędzia pozwalają na śledzenie społeczności internautów i reagowanie na ich zapytania oraz potrzeby.

\section{Rodzaje kryzysów w mediach społecznościowych}

Monika Czaplicka za Otto Lerbinerem wymienia 10 rodzajów kryzysów ${ }^{4}$ :

- Naturalne katastrofy - wydarzenia, które są spowodowane przez bezpośredni udział natury.

- Kryzysy technologiczne - związane z wydarzeniami, w których winna jest nauka lub technologia.

- Konfrontacja - sytuacje, gdzie ludzie stanowią siłę konfrontującą z organizacją i wyrażają swoje niezadowolenie z jej działalności.

- Wrogość - rodzaj kryzysu wywołany przede wszystkim przez agresywne działania przeciwnika lub konkurencji w celu dyskredytacji organizacji i pogorszenia wizerunku.

- Groźba ujawnienia tajnych danych, niewygodnych informacji - wiąże się często z próbą przekupstwa w celu dojścia do własnych korzyści.

- Organizacja - związany z błędami wynikającymi z organizacji pracy oraz z wyznawanymi przez pracowników wartościami.

$1 \quad$ Próba wynosiła 102 osoby.

2 Instytut Monitorowania Mediów, PR-owcu, co wiesz o social media?, http://www.imm.com.pl/sites/default/files/raporty/PR_a_social_media_PRoto_IMM.pdf, dostęp: 21.10.2017.

3 A. Chwiałkowska, Monitorowanie mediów społecznościowych jako kluczowy czynnik sukcesu przedsiębiorstwa, w: Zarządzanie i Finanse - Journal of Management and Finance, za: Comcowich, dostęp: 21.10.2017.

4 M. Czaplicka, Zarządzanie kryzysem w social media, Gliwice 2014, za: Otto Lerbinger, ss. 51-51. 
- Przemoc w miejscu pracy - mobbing oraz inne formy wykorzystywania.

- Pogłoski - są to plotki lub pomówienia, które szkodzą wizerunkowi organizacji.

- Ataki terrorystyczne/katastrofy spowodowane przez człowieka - w ten rodzaj kryzysów wliczają się też błędy social media managera, który obsługuje kanały social media organizacji.

- Niezadowolony klient - rodzaj najłatwiejszy do skontrolowania i przekucia w sukces przy prawidłowo poprowadzonej komunikacji.

\section{Wpływ kryzysu komunikacyjnego na wizerunek głowy państwa w Sieci}

Biorąc pod uwagę case study wybrane do niniejszego artykułu, które dotyczy Prezydenta Rzeczypospolitej Polskiej, mamy do czynienia z podejrzeniem możliwości wystąpienia kryzysu komunikacyjnego należącego spośród wymienionych wyżej rodzajów kryzysów do „wrogości” i „pogłosek”, które mogłyby zaszkodzić wizerunkowo Prezydentowi RP jak i urzędowi, który sprawuje w Kancelarii Prezydenta.

Kryzys związany z wrogością mógł być generowany przez zwolenników przeciwnego obozu politycznego, z którego wywodzi się Andrzej Duda, jak również przez osoby niemające skonkretyzowanych preferencji politycznych, ale przeciwni urzędowi prezydenta mającego rodowód partii Prawo i Sprawiedliwość. Ten rodzaj kryzysów generował najwięcej przejawów hejtingu i trollingu. Jest on definiowany jako agresywne formy wypowiedzi online. Wyrażają się one w formie tekstowej w postaci komentarzy lub formie graficznej, gdzie prym wiodą memy. Agresywne zachowania mogą być skierowane zarówno wobec osób fizycznych nieznanych, jak i wobec osób publicznych z punktu widzenia rozpoznawalności lub urzędu jaki pełnią ${ }^{5}$. Warto, aby osoby czuwające nad wizerunkiem głowy państwa śledziły takie wypowiedzi i reagowały w momentach, kiedy któreś z nich przekraczają prawo funkcjonujące w Sieci.

Drugi rodzaj kryzysu wyrażony w pogłoskach jest z kolei związany z tzw. „,ianiem plotek", które w internecie, a tym bardziej w przestrzeni mediów społecznościowych, mogą zyskać na niemałej popularności. Ceną takiego przebiegu wydarzeń może być nieprawdziwa informacja, która trafi do obiegu mediów masowych, a co za tym idzie, do milionowej rzeszy odbiorców. Nieprawdziwą informację, która została podana, jako oficjalna trudno jest odwrócić. Dlatego sztab dbający o wizerunek powinien „pogłoski” wychwytywać, analizować, wyciągać wnioski i natychmiast reagować w postaci dementowania plotek i podania oficjalnego stanowiska urzędu.

\section{Twitter, jako narzędzie komunikacji kreujące wizerunek w social media}

Biorąc pod uwagę kanał komunikacji w mediach społecznościowych, jakim jest Twitter, możemy stwierdzić, że według badań ma on największe znaczenie, jeśli chodzi o kreowanie wizerunku w polityce. Twitter należy do mikroblogów, który służy zaspokajaniu potrzeby informacji oraz dzielenia się treścią w postaci krótkich wiadomości tekstowych

5 M. Kaczmarek-Śliwińska, Zarządzanie komunikacją kryzysową w przestrzeni mediów społecznościowych w kontekście zjawiska hejtingu, „Kultura - Media - Teologia” 2016 nr 25, s. 47, dostęp: 21.10.2017. 
(tzw. tweetów). Pojawił się w marcu 2006 roku i stał się pierwszym systemem mikroblogowym na świecie 6 .

Dane Instytutu Monitorowania Mediów z monitoringu prasy, radia i TV z okresu 1.08.2012-31.07.2014 donoszą, że w ciągu 2 lat nastąpił trzykrotny wzrost cytowalności informacji z mediów społecznościowych ze średniej liczby 400 do 1200 . Wśród najczęściej cytowanych wymieniany jest Twitter i stanowi ok. 47\% w ogólnej liczbie cytowań. Jeśli chodzi o procentowy udział cytowań informacji z Twittera, pojawiają się kolejno w radiu $(75 \%)$, TV (68\%) oraz prasie (35\%). Najczęściej cytowane są tweety o tematyce politycznej ${ }^{7}$.

Twitter oznacza nie tylko mówienie, ale w równej mierze słuchanie obecnego tam środowiska. Często politykom wydaje się, że nie muszą tego robić, wystarczy, że zadbają o content i będą go publikować niemal z automatu. Później jednak może nastąpić zaskoczenie kryzysem wizerunkowym. A badając opinię społeczną i włączając system wczesnego ostrzegania o wydarzeniach można się od tego ustrzec ${ }^{8}$.

Dlatego dla wielu opiniotwórczych osób Twitter to również narzędzie, którym posługują się rzecznicy prasowi. Udostępniają oni informacje w imieniu swojej instytucji, organizacji lub firmy, którą reprezentują w mediach. Dzięki Twitterowi rzecznik prasowy nie musi pisać rozbudowanych komunikatów prasowych, czy sprostowań do prasy. Jeśli konto jest prowadzone imiennie, informacja tam zamieszczona staje się oficjalnym stanowiskiem organizacji ${ }^{9}$. Dlatego warto monitorować, o czym się mówi na Twitterze, który stał się kanałem, gdzie polityka jest dominującym tematem, a zarazem kopalnią wiedzy dla rzeczników instytucji publicznych (w tym ważnych osób w państwie) i stanowi oręże dla tzw. działań proaktywnych w komunikacji, które pomogą zażegnać kryzys dezinformacji, zanim on jeszcze powstanie.

\section{Case study}

4 marca 2016 roku doszło do wypadku z udziałem prezydenckiej limuzyny, który miał miejsce w czasie podróży Andrzeja Dudy do Wisły autostradą A4 w województwie opolskim w okolicach Lewina Brzeskiego. Samochód wpadł w poślizg i uderzając w bariery ochronne zsunął się do rowu. Po wstępnych oględzinach na miejscu zdarzenia okazało się, że pękła tylna opona, która była bezpośrednią przyczyną wypadku. W Sieci natychmiast rozgorzała dyskusja na temat przyczyny wypadku oraz samego uczestnika, którym była najważniejsza osoba w państwie w postaci Prezydenta RP.

Jednym z kanałów mediów społecznościowych, gdzie wielu internautów włączyło się w dyskusję był Twitter. Dzięki dowolnemu narzędziu do monitoringu mediów można odczytać wpisy złożone z kilku lub kilkunastu tysięcy tweetów. Można spraw-

$6 \quad$ Taż, Public relations w przestrzeni mediów społecznościowych. Działania organizacji i jej pracowników, Koszalin 2013, ss. 85-86.

7 M. Tokaj, Ł. Jadaś, A. Sanowska, Media 360. Od analityki do sprzedaży, Warszawa 2016, s. 12.

8 E. Mistewicz, Twitter-sukces komunikacji w 140 znakach. Tajemnice narracji dla firm, instytucji i liderów opinii, Gliwice 2015, s. 85.

9 M. Przybysz, Koniec Twittera? A może kolejny etap rozwoju?, „Nowe Media” 2015 nr 9, s. 69. 
dzić, kto był autorem wpisu, jaki był jego wydźwięk, jakie były reakcje (pozytywne, negatywne, czy neutralne), ile było tweetów autorskich, a ile retweetów (RT), czyli podań dalej przez innych użytkowników Twittera.

Celem niniejszego artykułu jest zbadanie pod względem ilościowym reakcji na wiadomość o wypadku z udziałem prezydenckiej limuzyny w serwisie społecznościowym Twitter poprzez analizę danych, których przedmiotem są tweety internautów. Wszystko to, by dowiedzieć się, kiedy konwersacja na temat wypadku została rozpoczęta i jakie opinie przeważały - pozytywne, negatywne, czy neutralne.

\section{Metodologia}

Artykuł zawiera analizę ilościową tweetów z polskojęzycznego Twittera (łącznie z retweetami), które pochodzą z 3 dni: od 4 do 6 marca 2016 roku tj. w dniu wypadku oraz 2 dniach po wypadku, kiedy dyskusja na ten temat w Sieci miała największe natężenie. Postawione zostały następujące pytania badawcze:

- Kiedy rozpoczęło się tweetowanie o prezydenckim wypadku?

- Z jakiego konta po raz pierwszy podano informację o wydarzeniu?

- Jakie słowo spośród słów kluczowych było najpopularniejsze wśród wzmianek?

- Jakich aktywności było więcej - tweetów, czy RT?

- Jaki był wydźwięk opublikowanych wpisów (pozytywny, negatywny, czy neutralny)?

- Które profile newsowe osiągnęły największe zasięgi?

Materiał badawczy poddany analizie w fazie początkowej liczył 12486 rekordów. Dobrane zostały 3 słowa kluczowe: „Duda”, „limuzyna”, „,opona” wraz z zastosowaniem deklinacji tych wyrazów przez przypadki.

Jednostkę analizy stanowił wpis zawierający przynajmniej jedno słowo kluczowe i należący do analizowanego tematu. Badanie wpisów miało charakter jedynie ilościowy, nie jakościowy. Do badania zostało wykorzystane narzędzie do analizy firmy Newspoint.

\section{Wyniki badań}

Analizując zagadnienie i wybierając spośród możliwych typów serwisów mikroblogi okazuje się, że Twitter nie był jedynym serwisem, który pojawił się w rezultatach. Oprócz niego były jeszcze widoczne wyniki z takich serwisów jak wykop.pl i pinger.pl.

\begin{tabular}{|l|r|r|r|r|}
\hline \multirow{2}{*}{ Nazwa serwisu } & \multicolumn{3}{|c|}{ Data } & \multirow{2}{*}{ Razem } \\
\cline { 2 - 4 } & $\mathbf{2 0 1 6 - 0 3 - 0 4}$ & $2016-03-05$ & $\mathbf{2 0 1 6 - 0 3 - 0 6}$ & \\
\hline pinger.pl & & 2 & & $\mathbf{2}$ \\
\hline Twitter & 3576 & 5594 & 2506 & $\mathbf{1 1 6 7 6}$ \\
\hline wykop.pl & 150 & 393 & 265 & $\mathbf{8 0 8}$ \\
\hline Razem & $\mathbf{3 7 2 6}$ & $\mathbf{5 9 8 9}$ & $\mathbf{2 7 7 1}$ & $\mathbf{1 2 4 8 6}$ \\
\hline
\end{tabular}

Tabela 1: Mikroblogi i ich wyniki wygenerowane w ciągu 3 dni (źródło: Newspoint). 


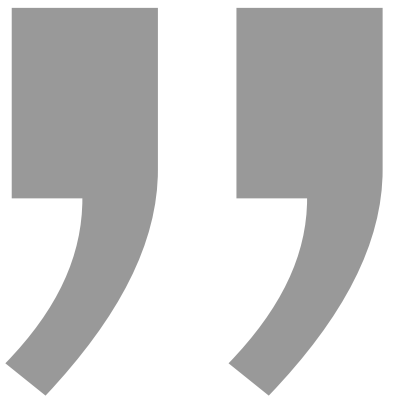

Twitter to również narzędzie, którym posługująą się rzecznicy prasowi. Udostępniają oni informacje w imieniu swojej instytucji, organizacji lub firmy, którą reprezentują w mediach. Dzięki Twitterowi rzecznik prasowy nie musi pisać rozbudowanych komunikatów prasowych, czy sprostowań do prasy.

Dane pokazują, że najwięcej wpisów powstało na Twitterze, a wykop.pl był mało znaczącym kanałem, zaś pinger.pl praktycznie nie liczył się w dyskusji. Wpisy z innych mikroblogów należy wykluczyć z badania, by pozostał jedynie Twitter. Służy to przestrzeganiu zasady rzetelności badawczej, jeśli analiza miałaby dotyczyć tylko jednego typu serwisu społecznościowego.

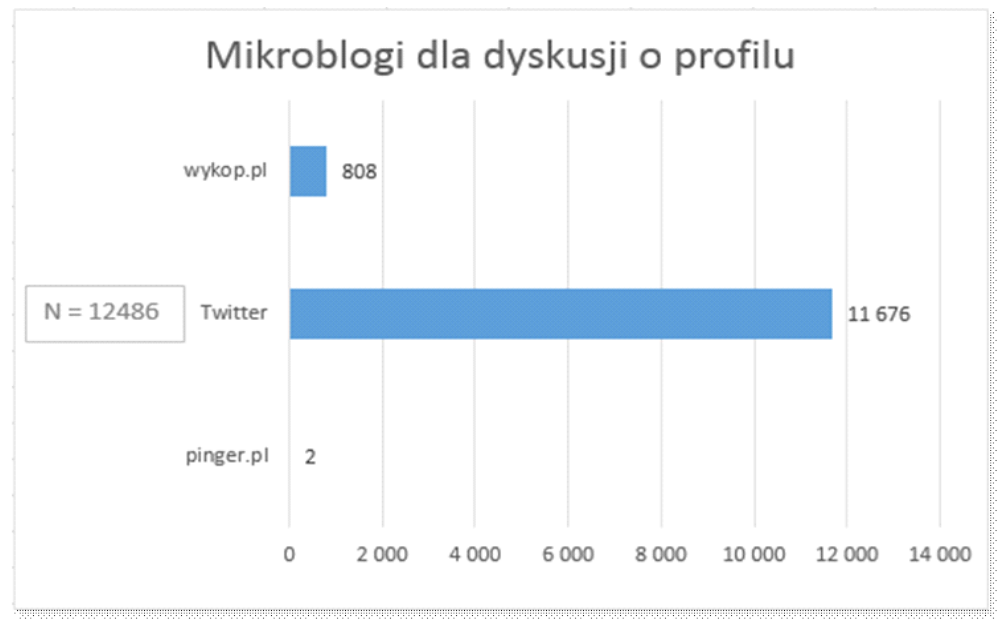

Wykres 1: Mikroblogi, na których toczyła się dyskusja (źródło: Newspoint).

Wiedząc, że Twitter był dominującym kanałem komunikacji w temacie wypadku z udziałem prezydenckiej limuzyny można zauważyć, że 5 marca był dniem pojawienia się największej liczby wzmianek trzech kluczowych wyrazów, które zostały użyte do badania. Przyczyną natężenia komunikacyjnego dzień po wypadku była pora samego wydarzenia mającego miejsce późnym popołudniem, co sprawiło, że dyskusja trwała wieczorem i przeniosła się na następny dzień liczony od północy. W kolejnych dniach aktywność użytkowników sukcesywnie spadała, co widać na słupkach z dnia 6 marca, będącego ostatnim dniem obejmującym badanie (wykres 2). 
Intensywność publikowanych tweetów - 04-06.03.2016 r.

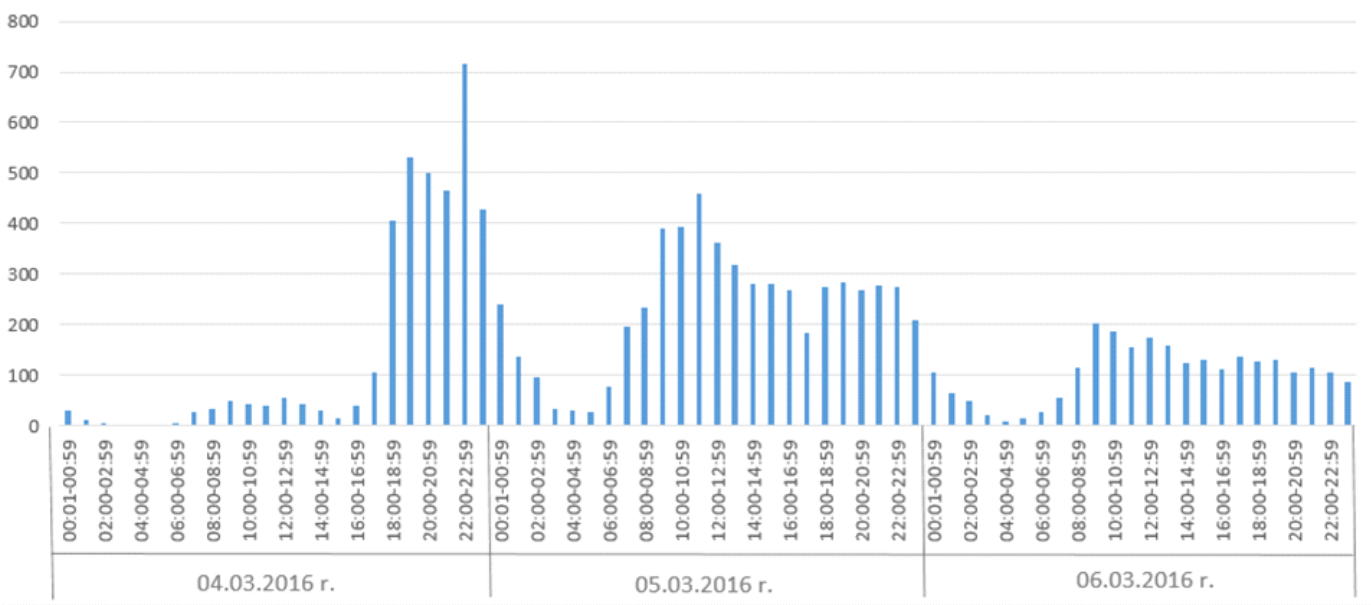

Wykres 2: Intensywność publikowanych tweetów w czasie (N=11 676).

Okazuje się, że tylko dzięki narzędziu analitycznemu do badania mediów społecznościowych możemy precyzyjnie wskazać, na którym profilu po raz pierwszy pojawiła się informacja o wydarzeniu.

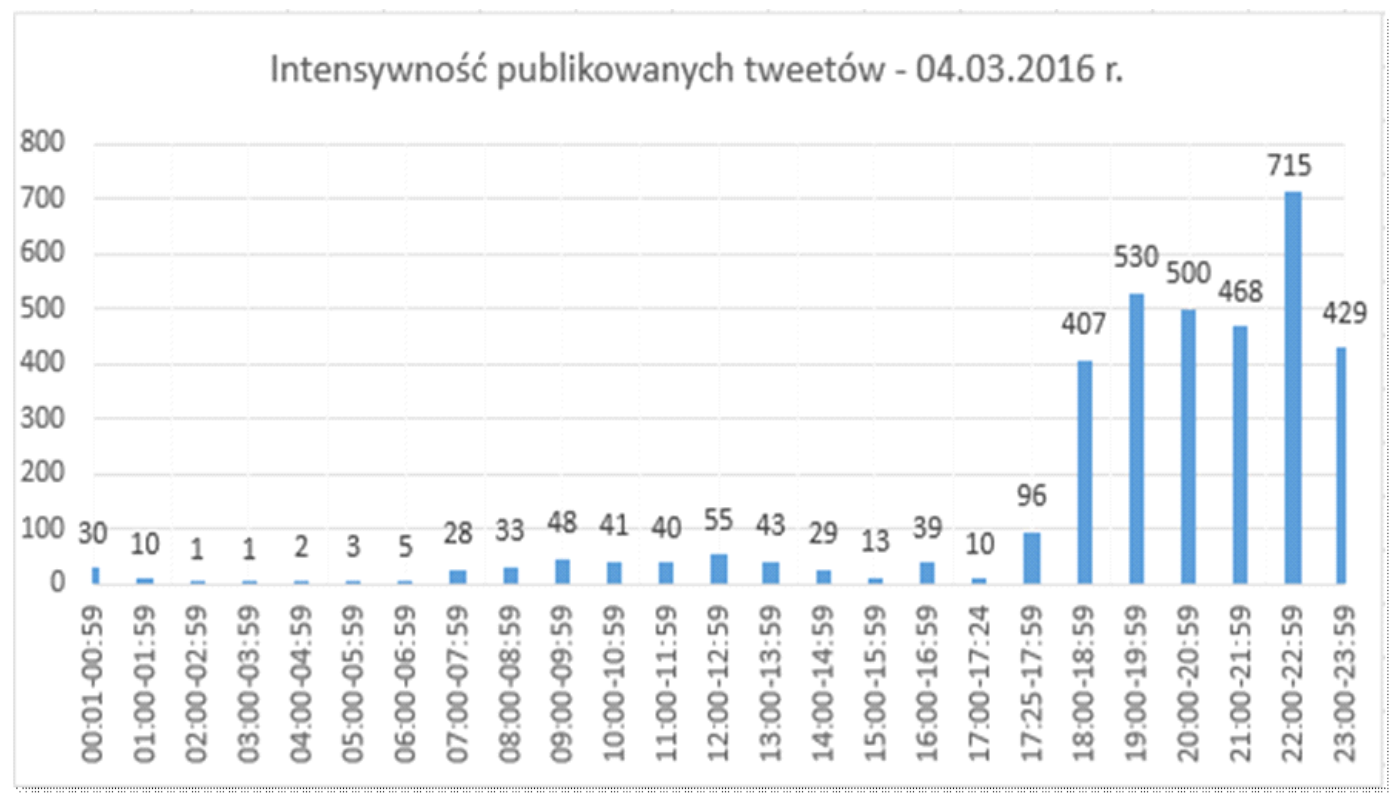

Wykres 3: Intensywność publikowanych tweetów w dniu wypadku. 
Analiza wykazała, że pierwszą wzmiankę o wypadku na Twitterze podał profil Faktów RMF FM (@RMF24pl) dokładnie o godz. 17:24, co można wyczytać z danych podanych przez narzędzie Newspointa. Próbując znaleźć taką informację jedynie w serwisie Twitter w sposób ręczny, nie byłoby to możliwe, ponieważ czas podawania tej informacji przez inne serwisy dzieliło zaledwie kilka minut lub nawet kilka sekund. Narzędzie badawcze zaś po słowach kluczowych pokazało wyniki w postaci publikacji tweeta wraz z linkiem do newsa na stronie www RMF FM oraz z grafiką dodawaną do pilnych informacji.

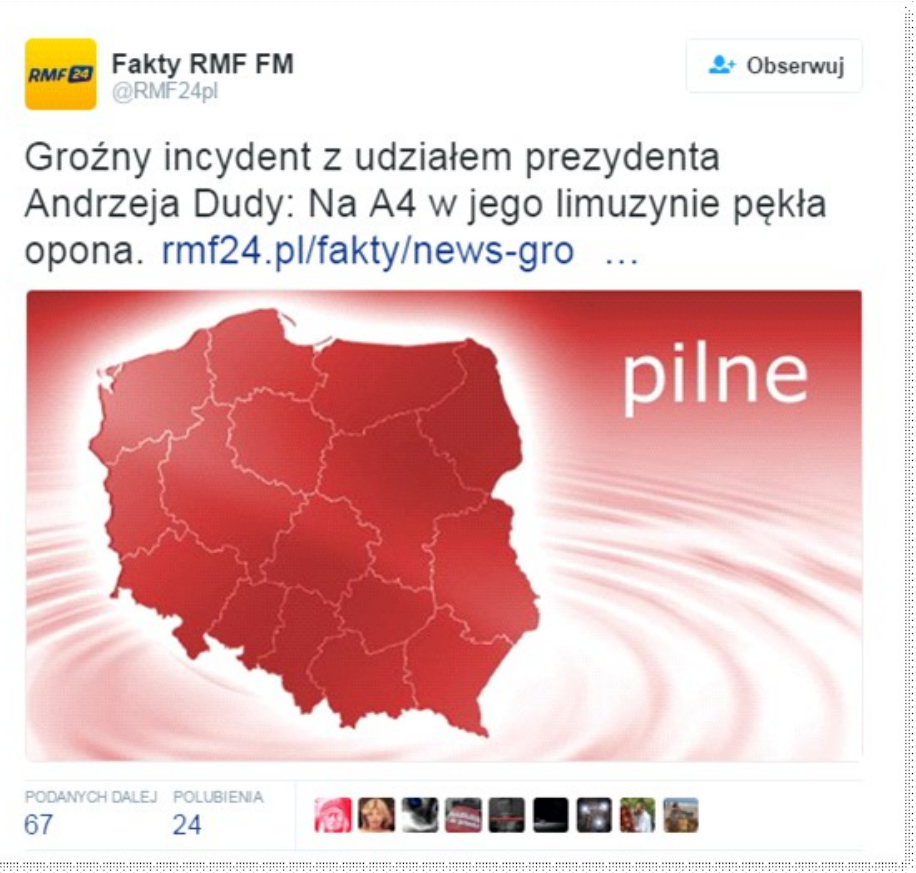

\section{Rysunek 1: Pierwsza wzmianka o wypadku (źródło: profil na Twitterze Fakty RMF FM @RMF24pl).}

Kolejną istotną kwestią jest popularność słów kluczowych w publikacjach na Twitterze w dniach 4-6 marca 2016. Słowo „opona” z deklinacją (opon*) pojawiło się 6946, kolejno „Duda” (Dud*) 4630 i „limuzyna” (limuzyn*), która osiągnęła 2107 rekordów. Należy przy tym zaznaczyć, że 2 lub wszystkie 3 słowa te mogły się zawierać w treści jednego tweeta, ale mogły również występować oddzielnie, co wpłynęło na możliwość wykazania ich popularności.

Analiza treści pozwoliła sprawdzić, czy spośród 11676 rekordów więcej było tweetów, czy raczej podań dalej zwanych w terminologii Twittera retweetami (RT). Okazało się, że w ujęciu procentowym autorskie tweety stanowiły 38\% badanego materiału, zaś retweety to aż $62 \%$ całości. Przeliczając procenty na dane liczbowe można stwierdzić, że napisano dokładnie 4423 tweetów i zretweetowano 7253 razy. Należy mieć jednak na 
uwadze, że mówimy tylko i wyłącznie o wpisach, które zawierały przynajmniej jedno ze słów kluczowych przedstawionych wcześniej. Główną przyczyną takiego rozkładu liczbowego może być charakter prezentowanej treści i wysiłek użytkownika serwisu, jaki ze sobą niesie.

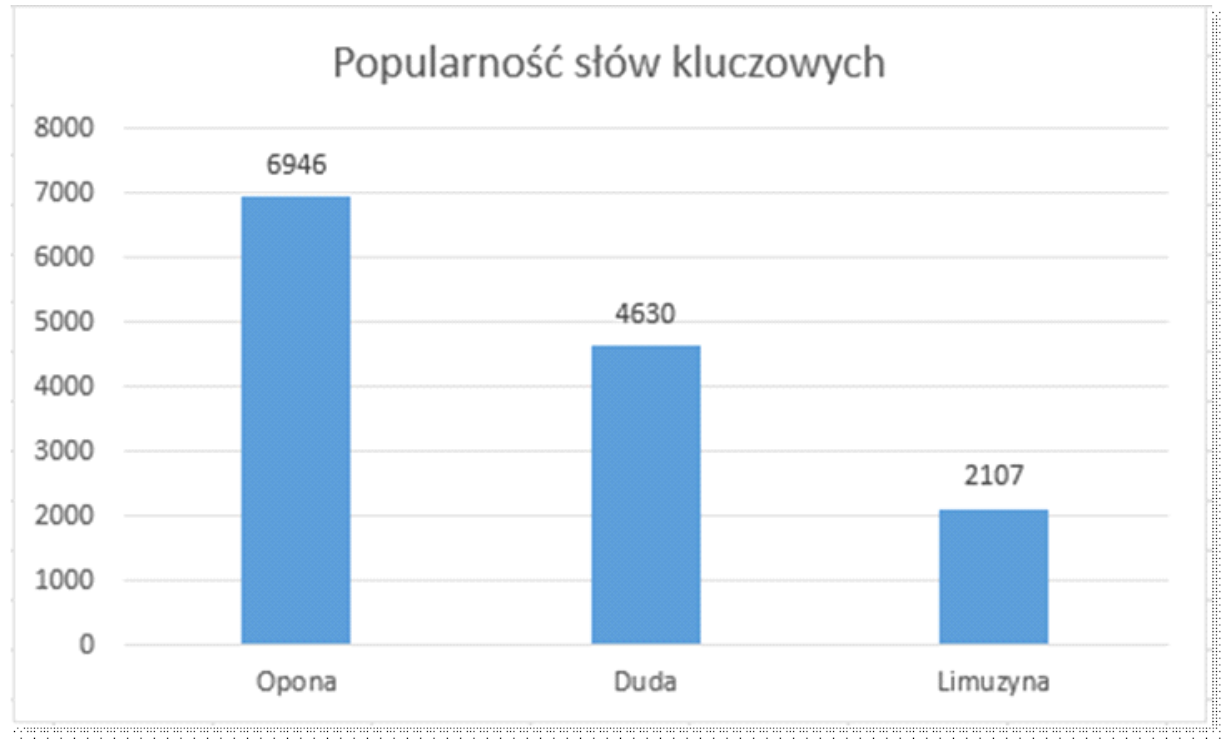

Wykres 4: Popularność słów kluczowych na Twitterze (źródło: Newspoint).

Tweet jest osobistym podzieleniem się na temat wydarzenia i wymaga większego zaangażowania ze strony internauty. Zaś retweet polega jedynie na udostępnieniu napisanej już treści dalej, do wiadomości innych obserwujących profil tej osoby. Warto zaznaczyć, że tweety są retweetowane zarówno wtedy, kiedy użytkownik zgadza się z ich treścią jak i wtedy, kiedy nie utożsamia się z nią, ale chce się podzielić przeciwnym zdaniem. Wykres poniżej nie zawiera treści będących czymś pomiędzy tweetem a retweetem, czyli cytatów.

Narzędzie umożliwia również stwierdzenie, jaki był sentyment publikowanych wpisów w serwisie społecznościowym Twitter w temacie wypadku z udziałem prezydenckiej limuzyny, przy zastrzeżeniu, że użyli przynajmniej jednego ze wskazanych słów kluczowych. Badanie pokazało, że najliczniejszą grupą były tweety neutralne - 7728 tweetów, co stanowi $66 \%$ całości. Wpisów uznanych za negatywne było 3030 tj. $26 \%$. Zaś wpisów pozytywnych można było w wynikach zauważyć 918 , co stanowiło $8 \%$ udziału wszystkich tweetów.

Tak duża większość wpisów neutralnych może wynikać z jedynie informacyjnego nacechowania tweetów traktujących o wypadku. Co oznacza, że nie miały w sobie słów uznanych przez program za pozytywne ani negatywne. $Z$ drugiej zaś strony można stwierdzić, że system nie był w stanie przyporządkować większości wypowiedzi do pozytywnego lub negatywnego wydźwięku, dlatego bezpiecznie umieścił niezidentyfikowane obiekty w puli neutralnych. 
Można także zastanawiać się, czy wszystkie tweety przyporządkowane do pozytywnych na pewno niosły pozytywny wydźwięk. Żaden bowiem program do analizy mediów nie wykrywa tzw. ironii, czy sarkazmu, które sprawiają, że w aspekcie dosłownym wpis może być odczytywany jako pozytywny, ale umiejscowiony w danym kontekście ma charakter negatywny.

Udział tweetów i retweetów w ogólnej liczbie rekordów

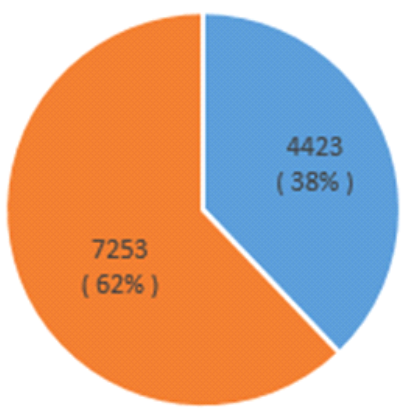

N=11676 - Liczba tweetów = Liczba retweetów

Wykres 5: Udział tweetów i retweetów w ogólnej liczbie rekordów (źródło: Newspoint).

\section{Podział tweetów ze względu na wydźwięk}

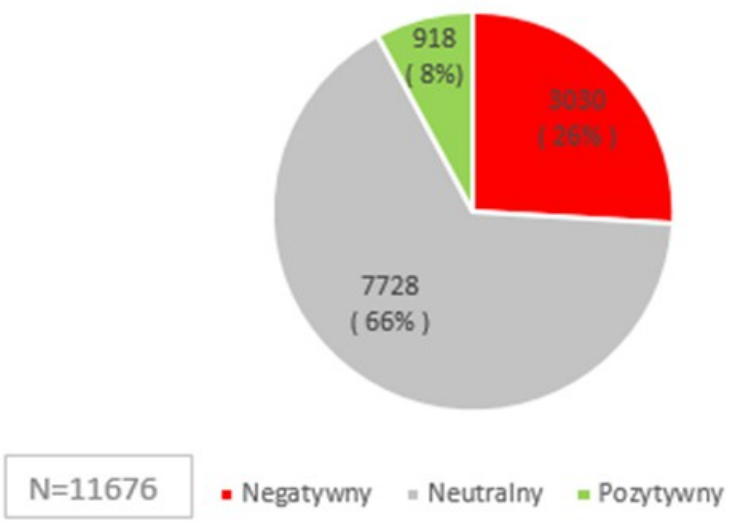

Wykres 6: Podział tweetów ze względu na wydźwięk (źródło: Newspoint). 


\section{HEJT I TROLLING W SIECI}

Ostatnim analizowanym elementem były twitterowe profile newsowe z najlepszymi zasięgami. $\mathrm{Z}$ danych udało się się wyodrębnić TOP 10 polskich serwisów, z których 4 osiągnęły zdecydowaną przewagę nad innymi. Najlepsze wyniki pod tym względem osiągnęło TVN24 z zasięgiem prawie 330 tys., następnie Gazeta Wyborcza z wynikiem prawie 200 tys., TVP Info z ponad 175 tys. i Tygodnik WPROST z ponad 126 tys. zasięgiem.

Wśród wyników nie ma serwisu, który wykazał się najszybszą publikacją informacji o wypadku. Może to wynikać z wielu przyczyn, m.in. mniejszą liczbą followersów, czy mniejszą liczbą publikowanych tweetów o wydarzeniu, co sprawiło, że temat przestał istnieć na profilu Faktów RMF FM.

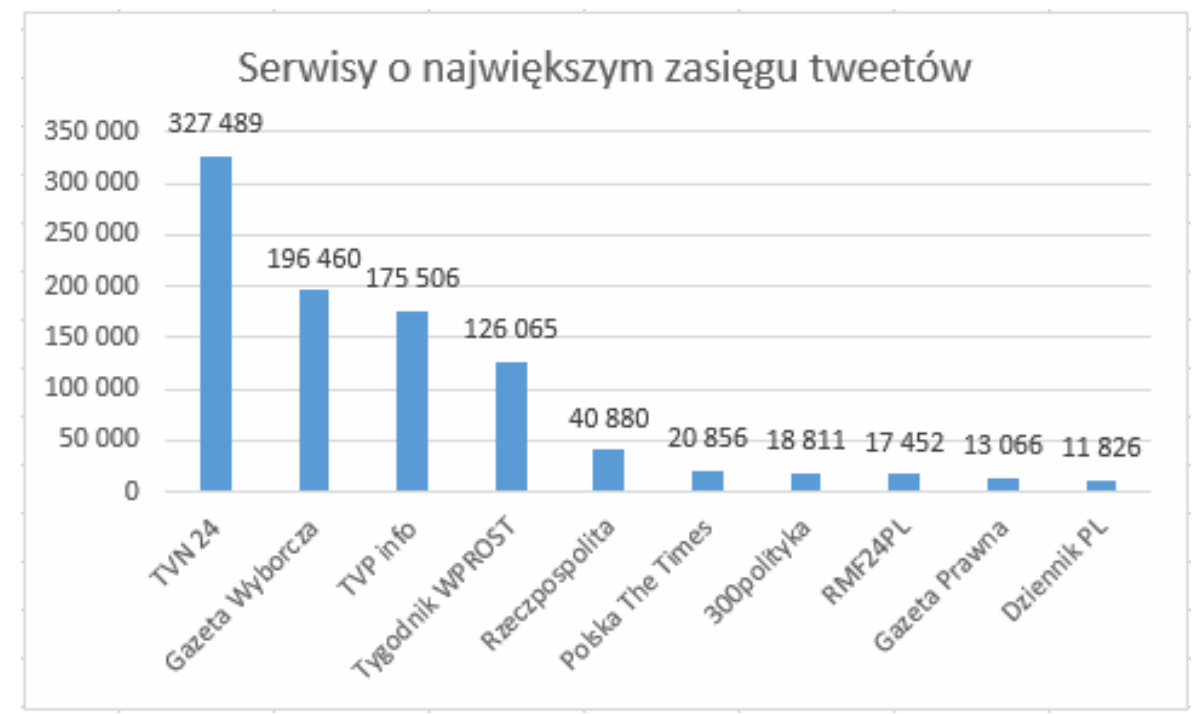

Wykres 7: Podział tweetów ze względu na wydźwięk (źródło: Newspoint).

\section{Podsumowanie i wnioski}

W powyższym artykule podjęto temat możliwego kryzysu wizerunkowego, wynikającego z dużej liczby negatywnych opinii na kanale społecznościowym Twitter dotyczących wypadku z udziałem prezydenckiej limuzyny. Dzięki dostępowi do narzędzia do monitoringu mediów firmy Newspoint oraz pogłębionej analizie sformułowano następujące wnioski:

- temat podejmowany w niniejszym artykule charakteryzował się dużym zaangażowaniem wśród Twitterian, a świadczy o tym ponad 11-tysięczny zbiór materiałów do analizy ilościowej;

- największy ruch w polskojęzycznym Twitterze miał dzień po zdarzeniu, spowodowany faktem, iż czas wypadku doszło późnym popołudniem;

- największą popularność wśród słów kluczowych wybranych przez autora tekstu zyskała „opona”, a wynika to z tego, iż było to słowo łączące większość wątków o tym wydarzeniu; 
- wśród wyników nad tweetami dominowały retweety, czyli odtwórczy charakter wypowiedzi;

- wśród profili, które miały największe zasięgi uplasowały się głównie profile newsowe tj. TVN24, Gazeta Wyborcza, TVP Info, czy Tygodnik WPROST; wynika to najprawdopodobniej z wielości prezentowanych treści o wydarzeniu oraz dużej liczby followersów;

- według wyników sentymentów, tweetów negatywnych było mniej niż $25 \%$, co może świadczyć o tym, że na tle liczby pozytywnych wpisów zyskały sporą popularność na Twitterze, co jest przykładem na pogłębiającą się mowę nienawiści w Sieci.

\section{BIBLIOGRAFIA:}

Chwiałkowska A., Monitorowanie mediów społecznościowych jako kluczowy czynnik sukcesu przedsiębiorstwa, w: Zarządzanie i Finanse - Journal of Management and Finance.

Czaplicka M., Zarządzanie kryzysem w social media, Gliwice 2014.

Instytut Monitorowania Mediów, PR-owcu, co wiesz o social media?, http://www.imm.com.pl/sites/default/files/raporty/PR_a_social_media_PRoto_IMM.pdf.

Kaczmarek-Śliwińska M., Public relations w przestrzeni mediów społecznościowych. Działania organizacji i jej pracowników, Koszalin 2013.

Kaczmarek-Śliwińska M., Zarządzanie komunikacją kryzysową w przestrzeni mediów społecznościowych $w$ kontekście zjawiska hejtingu, „Kultura Media - Teologia” $2016 \mathrm{nr} 25$, s. 46-58.

Mistewicz E., Twitter-sukces komunikacji w 140 znakach. Tajemnice narracji dla firm, instytucji i liderów opinii, Gliwice 2015.

Przybysz M., Koniec Twittera? A może kolejny etap rozwoju?, „Nowe Media” $2015 \mathrm{nr} 9$.

Tokaj M., Jadaś Ł., Sanowska A., Media 360. Od analityki do sprzedaży, Warszawa 2015.

\section{OAUTORCE:}

mgr Karolina Ołtarzewska - absolwentka Dziennikarstwa i komunikacji społecznej na Uniwersytecie Kardynała Stefana Wyszyńskiego w Warszawie. Doktorantka w Instytucie Politologii UKSW. Prezes Koła Naukowego Public Relations w Social Media. Interesuje się nowymi mediami, PR i crisis management. Ma doświadczenie pracy ${ }_{w}$ TVN, Telewizji PolskiejS.A. oraz Telewizji Republika. Kontakt:k_oltarzewska@wp.pl 